\title{
Smoking and reverse cholesterol transport: evidence for gene- environment interaction
}

\author{
JaAkxo Kaprio', Robert E. Ferrell ${ }^{3}$, Bruce A. Kottke ${ }^{2}$ and Charles F. Sing' \\ 'Department of Human Genetics, University of Michigan Medical School, Ann Arbor, Michigan; \\ ${ }^{2}$ Division of Cardiovascular Diseases, Mayo Clinic and Mayo Foundation, Rochester, Minnesota; \\ and ${ }^{3}$ Human Genetics Division, Graduate School of Public Health, University of Pittsburgh, \\ Pittsburgh, Pennsylvania, USA
}

Received 26 May, accepted for publication 27 May 1989

Lipid metabolism, like all other life processes, is determined by genetic factors, environmental influences and their joint action. In quantitative genetics we usually model this process as the linear effects of genes, environment and their interactions. Recently Kondo et al. (1989) reported that DNA polymorphisms at the locus for human cholesteryl ester transfer protein (CETP) were associated with interindividual differences in plasma levels of apolipoprotein A-I. The genetic effect was found in nonsmokers only. We report here another example of the role of gene-environment interaction in determining the components of lipid metabolism.

We have examined the impact of a polymorphic structural variation of a candidate gene, Apolipoprotein (apo) $\mathrm{H}$, on nine lipid and apolipoprotein phenotypes (Kaprio et al. 1989). Apo $\mathrm{H}$ has recently been assigned to the class of apolipoproteins, but its physiological role is still poorly understood. Structural heterogeneity of apo $\mathrm{H}$ has recently been determined (Kamboh et al. 1988) and three common alleles of the structural gene coding for the protein have been observed in Caucasians.
We identified 567 unrelated adults aged 26-62 from the Rochester Family Heart Study (Moll et al. 1989, Turner et al. 1989). After excluding persons $(n=72)$ using medications that may influence plasma lipid levels and those who had not been genotyped for apo $H(n=15), 480$ persons (240 men, 140 women) formed the sample for analysis. Ninety-two were current smokers and 388 had never smoked or were former smokers.

We found (Kaprio et al. in preparation) that smoking has a significant effect on HDL-cholesterol, apo A-I and apo A-II levels (adjusted for date of assay, age, age ${ }^{2}$, weight and height) in men and women. As the apo $\mathrm{H}$ polymorphism showed significant effects after each phenotype was also adjusted for smoking status, we decided to test for an interaction between apo $\mathrm{H}$ genotypes and smoking. The rarer genotypes of apo $\mathrm{H}$ were combined in this analysis to create two groups: genotype apo H $2-2(n=390)$ and all others $(n=90)$. HDL-cholesterol, apo AI and apo A-II values were adjusted by linear regression for date of assay, age, age ${ }^{2}$, weight and height for each gender separately. A general linear model (SAS Institute 
Inc. 1985) was used with three independent variables: smoking status (current vs noncurrent), genotype (apo H 2-2 vs. others) and gender to test for main effects and interactions. Results for the analysis of apo AII are shown in Table 1. The three-way interaction of gender, smoking and genotype was non-significant. Thus the three two-way interactions could be examined. Only the interaction of genotype and smoking was found to be statistically significant at the 0.05 level of probability. The main effects were significant for genotype and smoking. The effect of smoking was to decrease apoAII levels in subjects with the apo $\mathrm{H} 2$ 2 genotype, but not in subjects with other genotypes. For HDL and apo-AI, the interactions of genotype and smoking were not statistically significant.

Apo A-I and apo A-II are the major protein components of HDL, which participates in the 'reverse cholesterol transport' of excess cholesterol from the extrahepatic tissues to the liver for catabolism. CEPT is also involved in this process. Smoking is known to depress levels of HDL-cholesterol and apo A-I (Berg et al. 1979), as was found in the present study. Our study and the report of Kondo et al. (1989) suggest that the effects of smoking are dependent on the genotype of certain genes coding for proteins participating in reverse cholesterol transport. We can only speculate on the mechanism for this process, because smoking affects many metabolic parameters (Laustiola et al. 1988). There may be chemical components of tobacco smoke that directly modify the composition or structure of HDL-particles. Alternatively smoking may alter the physicochemical milieu, which indirectly affects the metabolic pathways that are involved. It is known that smoking has a significant impact on quantitative levels of a number of plasma proteins involved in determining cardiovascular disease risk (Berg et al. 1979, Wilhelmsen et al.

Table 1

Interaction of smoking with apo $\mathrm{H}$ genotypes on levels of apo A-II. Mean levels of apo A-II (mg/ dl) by smoking status and apo-H genotype (2-2 vs non:2-2) in unrelated individuals from Rochester, Minnesota. ( $N$ of subjects in parentheses)

\begin{tabular}{|c|c|c|c|c|c|c|}
\hline \multirow{2}{*}{$\begin{array}{l}\text { Smoking } \\
\text { status }\end{array}$} & \multicolumn{2}{|c|}{$\begin{array}{c}\text { Men } \\
\text { Genotype }\end{array}$} & \multicolumn{2}{|c|}{$\begin{array}{l}\text { Women } \\
\text { Genotype }\end{array}$} & \multicolumn{2}{|c|}{$\begin{array}{c}\text { Total } \\
\text { Genotype }\end{array}$} \\
\hline & 22 & Non-22 & 22 & Non-22 & 22 & Non-22 \\
\hline Smoker & $\begin{array}{c}32.25 \\
(39)\end{array}$ & $\begin{array}{c}36.21 \\
(8)\end{array}$ & $\begin{array}{c}31.55 \\
(31)\end{array}$ & $\begin{array}{l}33.13 \\
(10)\end{array}$ & $\begin{array}{c}31.94 \\
(70)\end{array}$ & $\begin{array}{l}34.50 \\
(18)\end{array}$ \\
\hline Non-smoker & $\begin{array}{l}34.91 \\
(159)\end{array}$ & $\begin{array}{l}34.12 \\
(34)\end{array}$ & $\begin{array}{l}34.34 \\
(161)\end{array}$ & $\begin{array}{l}35.25 \\
(38)\end{array}$ & $\begin{array}{l}34.64 \\
(320)\end{array}$ & $\begin{array}{l}34.71 \\
(72)\end{array}$ \\
\hline
\end{tabular}

\begin{tabular}{lccc}
\hline $\begin{array}{l}\text { Analysis of variance } \\
\text { Source }\end{array}$ & Partial Sum of Squares & F-value & P-value \\
\hline $\begin{array}{l}\text { Main effects: } \\
\text { Smoking }\end{array}$ & 84.9 & 4.42 & 0.036 \\
Genotype & 91.1 & 4.74 & 0.030 \\
Gender & 29.6 & 1.54 & 0.22 \\
Two-way interections: & & & 0.037 \\
Genotype by smoking & 84.0 & 4.37 & 0.09 \\
Smoking by gender & 53.9 & 0.81 & 0.79 \\
Genotype by gender & 1.32 & & 0.12 \\
Three-way interaction: & & 2.46 & \\
Genotype by gender by smoking & 47.3 & & \\
\hline
\end{tabular}


1984). It will be of interest to determine whether these effects are genotype specific.

\section{Acknowledgements}

This work was supported by National Institutes of Health grants HL24489 and HL39107. Dr. Kaprio was a recipient of a Ciba Foundation Bursary.

\section{References}

Berg, K., A.-L. Børresen \& G. Dahlén (1979). Effect of smoking on serum levels of HDL apoproteins. Atherosclerosis 34, 339-343.

Kamboh, M. I., R. E. Ferrell \& B. Sepehrnia (1988). Genetic studies of human apolipoproteins. IV. Structural heterogeneity of apolipoprotein $\mathrm{H}$ (beta-2-glycoprotein I). Am. J. Hum. Genet. 42, 452-457.

Kondo, I., K. Berg, D. Drayna \& R. Lawn (1989) DNA polymorphism at the locus for human cholesteryl ester transfer protein (CETP) is associated with high density lipoprotein cirolesterol and apolipoprotein levels. Clin. Genet. 35, 49-56.

Kaprio, J., R. E. Ferrell, B. A. Kottke, S. T. Turner \& C. F. Sing (1989). Effect of polymorphisms in apolipoprotein $\mathrm{E}, \mathrm{A}-\mathrm{IV}$ and $\mathrm{H}$ on quantitative traits related to risk for cardiovascular disease. In preparation.
Laustiola, K., R. Lassila, J. Kaprio \& M. Koskenvuo (1988). Decreased $\beta$-adrenergic receptor density and catecholamine response in male cigarette smokers. A study of monozygotic twin pairs discordant for smoking. Circulation 78, 1234-1240.

Moll, P., V. Michels, W. Weidman \& B. Kottke (1989). The genetic determination of plasma apolipoprotein AI in a population-based sample. Am. J. Hum. Genet. 44, 124-139.

SAS Institute Inc. (1985). SAS User's Guide: Statistics, Version 5 Edit. Cary, NC: Sas Institute Inc.

Turner, S. T., W. Weidman, V. Michels, T. Reed, C. Ormson, T. Fuller \& C. F. Sing (1989). Distribution of sodium-lithium countertransport and blood pressure in caucasians 5 to 89 years of age. Hypertension 13, 378-391.

Wilhelmsen, L., K. Svärdsudd, K. KorsenBengtsen, B. Larsson, L. Welin \& G. Tibblin (1984). Fibrinogen as a risk factor for stroke and myocardial infarction. N. Engl. J. Med. 311, 501-505.

Address:

Professor Charles F. Sing

Department of Human Genetics

The University of Michigan Medical School Medical Science II M4708

Ann Arbor, MI 48109-0618

U.S.A. 